\title{
Histone Deacetylase, Xanthine Oxidase and Urease Inhibitory Activities of Eremurus spectabilis M. Bieb. Extracts
}

\author{
Eremurus spectabilis Bieb. Ekstrelerinin Histon Deasetilaz, Ksantin Oksidaz ve \\ Üreaz İnhibitör Aktiviteleri
}

\author{
Bertan Boran Bayrak' (D), Refiye Yanardag' (1) \\ 'Department of Chemistry, Faculty of Engineering, Istanbul University-Cerrahpasa, Istanbul, Turkey
}

ORCID ID: B.B.B. 0000-0002-0700-5096; R.Y. 0000-0003-4185-4363

Cite this article as: Bayrak BB, Yanardag R. Histone deacetylase, xanthine oxidase and urease inhibitory activities of Eremurus spectabilis M. Bieb. extracts. Experimed 2021; 11(3): 156-61.

\begin{abstract}
Objective: Natural ingredients derived from plants (especially edible ones) continue to be investigated for understanding whether they have therapeutic/preventive effects on certain ailments, such as cancer and gastrointestinal disorders. The main goal of the current work is to investigate the inhibitory potential of Eremurus $(E)$ spectabilis M. Bieb. extracts on histone deacetylase (HDAC), xanthine oxidase $(\mathrm{XO})$ and urease activities.
\end{abstract}

Material and Method: Fresh E. spectabilis leaves were obtained from a local market in Eyup/Istanbul. Inhibitory activities of ethanolic and ethyl acetate extracts on HDAC, XO and urease were examined.

Results: According to our findings, ethanolic and ethyl acetate extracts of E. spectabilis both have revealed apparent inhibitory effects against all examined enzymes. Ethanolic extract showed a better inhibitory effect on HDAC than ethyl acetate extract. On the other hand, the inhibitory effects of ethyl acetate extract against both $\mathrm{XO}$ and urease were higher than the ethanolic extract.

Conclusion: Consequently, due to the inhibitory effects of the plant being studied, it might be suggested that it can be used for medicinal purposes, in raw extract form, or as a source of bioactive compounds.

Keywords: Eremurus spectabilis, histone deacetylase, xanthine oxidase, urease, inhibitory effect öz

Amaç: Bitkilerden elde edilen doğal bileşiklerin (özellikle yenilebilir olanlar), kanser ve gastrointestinal bozukluklar gibi belirli rahatsızIıklar üzerinde tedavi edici/önleyici etkilerinin olup olmadığı araştırılmaya devam etmektedir. Çalışmanın temel amacı, Eremurus (E) spectabilis M. Bieb. ekstrelerinin histon deasetilaz (HDAC), ksantin oksidaz $(X O)$ ve üreaz aktiviteleri üzerindeki inhibitör etkilerini araştırmaktır.

Gereç ve Yöntem: E. spectabilis'in taze yaprakları, Eyüp/Istanbul'da$\mathrm{ki}$, yerel bir pazardan temin edilmiştir. Etanol ve etil asetat ekstrelerinin HDAC, XO ve üreaz üzerindeki inhibitör aktiviteleri incelenmiştir.

Bulgular: Elde edilen sonuçlara göre, E. spectabilis'in hem etanol hem de etil asetat ekstrelerinin incelenen tüm enzimler üzerinde belirgin inhibitör etkiye sahip olduğu bulunmuştur. Etanol ekstresi, HDAC üzerinde etil asetat ekstresinden daha iyi bir inhibisyon etkisi göstermiştir. Etil asetat ekstresinin ise, hem XO hem de üreaza karşı inhibisyon etkisinin, etanol ekstresinden daha yüksek olduğu görülmüştür.

Sonuç: Sonuç olarak, incelenen bitkinin gösterdiği inhibitör etkiler nedeni ile, bu bitkinin tıbbi amaçla, ham ekstre şeklinde veya biyoaktif bileşik kaynağı olarak kullanılabileceği ileri sürülebilir.

Anahtar Kelimeler: Eremurus spectabilis, histon deasetilaz, ksantin oksidaz, üreaz, inhibitör etki 


\section{INTRODUCTION}

Plants have been used as beneficial healing options to modern medicine, as well as being consumed by humans as food for many years. The investigation of the utility of herbs in the treatment of diseases becomes important, due to the possible side effects and considerable high cost of synthetic drugs (1). The genus Eremurus (Xanthorrhoeaceae) comprises 62 species and is widespread in the mountains of Central Asia and the Middle East (including Turkey) $(2,3)$. Two Eremurus species are grown naturally in Turkey. One of them is Eremurus (E) cappadocicus $\mathrm{J}$. Gay ex Baker and the other E. spectabilis which is named "çiriş otu, yabani pırasa, or güllük" between individuals (3). E. spectabilis grows naturally in some provinces of the Eastern Anatolian region of Turkey (4-6). In these regions, the plant is commonly used as not only a wild edible plant, but also as a medicinal plant whose leaves and roots are traditionally used to cure some disorders including diabetes, antihypertension, and eczema (7-9).

Naturally occurring secondary metabolites are found in vegetables and fruits include phenolic acids, flavonoids, and their derivatives. These compounds have a wide range of therapeutic effects (10). Medicinal plants such as E. spectabilis are good sources of these molecules. This is why they are frequently used as a potential inhibitor of enzymes (such as histone deacetylase (HDAC), xanthine oxidase (XO) and urease) which may play key roles in the overproduction of free radicals, thereby subsequently precipitating oxidative stress, cancer and gastrointestinal disorders (11).

HDAC is an enzyme responsible for removing acetyl groups from $\mathrm{N}$-terminal $\mathrm{N}^{\varepsilon}$-lysine residues of histone. In contrast, acetylation of histone is catalyzed by histone acetyltransferase. The acetylation and deacetylation of histones are strictly well balanced, this is because acetylation/deacetylation process is an important post-translational modification of histone. When an imbalance of the activities of these enzymes favors HDAC, deacetylation of histone brings about stronger histone-DNA interactions-a key factor for the regulation of mammalian gene expression. In addition, aberrant HDAC activity and/or expression of HDAC can lead to cancer induction/progression $(12,13)$.

Xanthine oxidoreductase (XOR) is an enzyme with multiple activities as follows: Xanthine dehydrogenase (XDH), nitrite reductase, NADH oxidase and xanthine oxidase (XO). Owing to its multiple enzymatic activities, XOR has crucial physiological functions. Notably, increased XO activity is accompanied by an overproduction of uric acid, and thus hyperuricemia (14). On the other hand, the increased activity of XO causes the formation of free radicals (both oxygen-centered and nitrogen-centered reactive species) that can degenerate or promote cancer development. More so, elevated levels of plasma XO activities in patients with certain disease conditions (e.g. cancer, metabolic disorder, and diabetes) have been reported (15). From this point of view, scientists have made great efforts to find new molecules with fewer side effects than the currently used XO inhibitors.
Urease belongs to a class of hydrolases enzyme that catalyzes the hydrolyzation of urea into ammonium ion, thereafter carbamate and subsequently converted into carbon dioxide. An apparent rise in urease activity as a consequence of high $\mathrm{pH}$ levels in human brings about various pathophysiological conditions such as gastrointestinal disorders, peptic ulcers, and gastric cancer as well. In these cases, ureases are accepted as a key reason for developing the aforementioned disorders owing to Helicobacter pylori infection $(16,17)$.

There are insufficient reports about the effects of E. spectabilis inhibitory activities against HDAC, XO and urease enzymes. Therefore, the main goal of this work was to determine the inhibition activities of ethanolic and ethyl acetate extracts of $E$. spectabilis against the HDAC, $\mathrm{XO}$ and urease enzymes.

\section{MATERIAL AND METHOD}

\section{Plant Material and Chemicals}

Fresh E. spectabilis leaves were obtained from a local market in Eyup/Istanbul, Turkey. The leaves were washed with distilled water and dried at room temperature. The dried plant was stored at $-20^{\circ} \mathrm{C}$ until required for use. The plant was inspected by Prof. Dr. Emine Akalin (Faculty of Pharmacy, Istanbul University). Also, it was registered at the Istanbul University Faculty of Pharmacy Herbarium (ISTE) with the number 93132.

The HDAC (fluorometric assay kit, CS1010-1KT), XO (from bovine milk), and urease (from jack beans) and their respective substrates were supplied from Sigma-Aldrich (St. Louis, MO). All of the chemicals used were of analytical grade.

\section{Preparation of Extracts}

The ethanolic and ethyl acetate extracts were prepared by refluxing $20 \mathrm{~g}$ of dried E. spectabilis leaves with either ethanolic or ethyl acetate for 2 hours in Soxhlet apparatus. The extracts were then filtered at room temperature, the solvents were evaporated under reduced pressure and controlled temperature $\left(40-50^{\circ} \mathrm{C}\right)$. The ethanolic $(87.32 \mathrm{mg} / \mathrm{g}$ dry weight) and ethyl acetate $(87.84 \mathrm{mg} / \mathrm{g}$ dry weight) extracts were obtained from E. spectabilis and they were kept at $-20^{\circ} \mathrm{C}$ prior to analysis.

\section{In vitro HDAC Inhibitory Activity}

HDAC inhibitory activity was evaluated based on the twostep enzymatic reaction. This was performed by measuring fluorescence in a fluorimeter plate reader as prescribed by the commercial assay kit. Valproic acid (VPA) was used as a standard. The results were expressed as the average of triplicate trials.

The percent inhibition of the HDAC was calculated using the following equation:

HDAC inhibitory activity $(\%)=[(A-B) / A] \times 100$

where $A$ represents the activity of the enzyme without an inhibitor, and $B$ is the activity of enzyme in the presence of the extract (or standard inhibitor). 


\section{In vitro XO Inhibitory Activity}

$\mathrm{XO}$ inhibitory activity was carried out by the spectrophotometric method of Abdullahi et al. (18). In brief, the reaction medium comprising of $0.1 \mathrm{M}$ phosphate buffer, $(\mathrm{pH} 7.50)$, a sample at varying concentrations, and $\mathrm{XO}$ solution $(0.1 \mathrm{U} / \mathrm{mL}$, in the same buffer) was mixed and allowed to stand at $25^{\circ} \mathrm{C}$ for $15 \mathrm{~min}$. Xanthine solution $(150 \mu \mathrm{M})$ was pipetted to the reaction medium and then incubated at $25^{\circ} \mathrm{C}$ for $15 \mathrm{~min}$. Thereafter $1 \mathrm{~N} \mathrm{HCl}$ was added to the mixture. The absorbance of the samples was recorded at $410 \mathrm{~nm}$. Allopurinol was used as a standard inhibitor. The results were expressed as the average of triplicate trials.

The percent inhibition of the XO was calculated using the following equation:

XO inhibitory activity $(\%)=[(A-B) / A] \times 100$

where $A$ represents the activity of the enzyme without an inhibitor, and $B$ is the activity of enzyme in the presence of the extract (or standard inhibitor).

\section{In vitro Urease Inhibitory Activity}

Urease inhibitory activity was assayed by the spectrophotometric method developed by Van Slyke and Archibald (19), in which urea is hydrolyzed over time to yield ammonia and carbon dioxide. Briefly, an assay mixture of a total volume of 1.9 $\mathrm{mL}$, containing extract solution (or standard inhibitor), phosphate buffer (100 mM, pH 6.8 and containing $500 \mathrm{mM}$ urea), and urease solution $(16 \mathrm{mg} / \mathrm{mL})$ was pre-incubated at room temperature for $15 \mathrm{~min}$. The reaction solution was mixed with appropriate volume of phenol-red solution, thereafter incubated at room temperature for $15 \mathrm{~min}$ again. After incubation, the absorbance was measured at $570 \mathrm{~nm}$. Hydroxyurea was used as a standard inhibitor. The results were expressed as the average of triplicate trials.

The percent inhibition of the urease was calculated using the following equation:

Urease inhibitory activity $(\%)=[(A-B) / A] \times 100$ where $A$ represents the activity of the enzyme without an inhibitor, and $B$ is the activity of enzyme in the presence of the extract (or standard inhibitor).

For HDAC, XO, and urease inhibitory activities, the extract (or standard) concentration providing half maximum (50\%) inhibitions $\left(I_{50}\right)$ was calculated by regression equations (by plotting extract solution concentration versus percentage inhibition). Low $I C_{50}$ indicates the higher inhibitory potential of the tested plant extracts.

\section{RESULTS}

The inhibition effects of ethanolic and ethyl acetate extracts of $E$. spectabilis as well as that of VPA against HDAC activity are summarized in Table 1. According to the results, ethanolic extract, ethyl acetate extracts and the standard had an $\mathrm{IC}_{50}$ value in the range of $0.99-101.83 \mu \mathrm{g} / \mathrm{mL}$. In addition, ethanolic and ethyl acetate extracts inhibited HDAC in a dose-dependent manner with $\mathrm{IC}_{50}$ values of $0.99 \pm 0.32$ and $8.60 \pm 0.49 \mu \mathrm{g} / \mathrm{mL}$, respectively. Considering the high inhibitory activities (associated with the lower $\mathrm{IC}_{50}$ values) these extracts demonstrated higher inhibitory activity against HDAC in comparison to VPA (IC $C_{50}$ values of $101.83 \pm 1.43 \mu \mathrm{g} / \mathrm{mL}$ ). The order for inhibitory effect is as follows: ethanolic extract $>$ ethyl acetate extract $>$ VPA (Table 1).

The inhibitory activities and $\mathrm{IC}_{50}$ values of ethanolic extracts, ethyl acetate extracts, and allopurinol on $\mathrm{XO}$ are given in Table 2. It was found that the XO inhibition increased in a concentration-dependent manner for all the extracts and the standard. At $500 \mu \mathrm{g} / \mathrm{mL}$ of both extracts, it was observed that the ethyl acetate extract had approximately 1.5 times more inhibition value $(46.16 \pm 2.34 \%)$ than ethanolic extract $(30.18 \pm 1.00 \%)$. Meanwhile, at the same concentration, the inhibition value of the ethyl acetate extract was very close to that of the standard inhibitor, allopurinol (52.34 $\pm 1.37 \%)$. However, the ethyl acetate extract had a lower $\mathrm{IC}_{50}$ value than that of ethanolic extract. On the other hand, the allopurinol had the lowest $I C_{50}$ value $(403.87 \pm 18.32 \mu \mathrm{g} / \mathrm{mL})$ in comparison to both ethyl acetate

Table 1. HDAC inhibitory activity of E. spectabilis extracts.

\begin{tabular}{lccc}
\hline Extracts/Standard & Concentrations $(\boldsymbol{\mu} \mathbf{g} / \mathbf{m L})$ & Inhibition $(\%) *$ & $\mathbf{I C}_{\mathbf{5 0}}(\boldsymbol{\mu} \mathbf{g} / \mathbf{m L})^{*}$ \\
\hline & 0.05 & $5.05 \pm 0.35$ & \\
Ethanolic Extract & 0.10 & $13.09 \pm 3.08$ & $0.99 \pm 0.32$ \\
& 0.50 & $28.84 \pm 7.69$ & \\
Ethyl Acetate Extract & 1.0 & $9.64 \pm 4.51$ & $8.60 \pm 0.49$ \\
& 2.0 & $18.48 \pm 2.32$ & \\
Valproic Acid & 5.0 & $31.24 \pm 0.73$ & $101.83 \pm 1.43$ \\
\end{tabular}


$(524.13 \pm 8.17 \mu \mathrm{g} / \mathrm{mL})$ and the ethanolic extracts $(658.89 \pm 5.55$ $\mu \mathrm{g} / \mathrm{mL}$ ) of $E$. spectabilis. The XO inhibitory activity of $E$. spectabilis extracts and the standard decreased in the order of: allopurinol > ethyl acetate extract $>$ ethanolic extract (Table 2).

The inhibitory activities and IC $C_{50}$ values of the ethanolic, ethyl acetate extracts, and hydroxyurea on urease are presented in Table 3. All of the extracts were found to exhibit urease inhibitory activities. A comparison indicates that ethyl acetate extract had approximately 5 times more inhibitory activity than the ethanolic extract. The IC 50 value of hydroxyurea $(2422.50 \pm 102.43 \mu \mathrm{g} /$ $\mathrm{mL}$ ) (used as standard inhibitor) was found to be much higher than that of both the ethanolic $(269.12 \pm 14.19 \mu \mathrm{g} / \mathrm{mL})$ and the ethyl acetate extracts $(47.15 \pm 1.63 \mu \mathrm{g} / \mathrm{mL}$ ), respectively (Table 3 ). The urease inhibitory activity of E. spectabilis extracts and the standard decreased in the order of: ethyl acetate extract $>$ ethanolic extract > hydroxyurea (Table 3).

Table 2. XO inhibitory activity of $E$. spectabilis extracts.

\begin{tabular}{|c|c|c|c|}
\hline Extracts/Standard & Concentrations ( $\mu \mathrm{g} / \mathrm{mL}$ ) & Inhibition (\%)* & $I C_{50}(\mu \mathrm{g} / \mathrm{mL})^{*}$ \\
\hline \multirow{5}{*}{ Ethanolic Extract } & 100 & $9.26 \pm 2.13$ & \multirow{5}{*}{$658.89 \pm 5.55$} \\
\hline & 250 & $18.44 \pm 2.26$ & \\
\hline & 500 & $30.18 \pm 1.00$ & \\
\hline & 750 & $53.46 \pm 1.00$ & \\
\hline & 1000 & $83.03 \pm 1.81$ & \\
\hline \multirow{5}{*}{ Ethyl Acetate Extract } & 100 & $9.62 \pm 0.74$ & \multirow{5}{*}{$524.13 \pm 8.17$} \\
\hline & 250 & $23.72 \pm 2.46$ & \\
\hline & 500 & $46.16 \pm 2.34$ & \\
\hline & 750 & $80.45 \pm 1.61$ & \\
\hline & 1000 & $88.14 \pm 1.23$ & \\
\hline \multirow{5}{*}{ Allopurinol } & 0.1 & $5.26 \pm 0.93$ & \multirow{5}{*}{$403.87 \pm 18.32$} \\
\hline & 1 & $21.78 \pm 2.85$ & \\
\hline & 10 & $40.65 \pm 2.08$ & \\
\hline & 100 & $47.47 \pm 1.14$ & \\
\hline & 500 & $52.34 \pm 1.37$ & \\
\hline
\end{tabular}

${ }^{*}$ Mean $\pm S D$; SD: Standard deviation; $\mathrm{IC}_{50}$ : Concentration providing half maximum $(50 \%)$ inhibition

Table 3. Urease inhibitory activity of E. spectabilis extracts.

\begin{tabular}{|c|c|c|c|}
\hline Extracts/Standard & Concentrations $(\mu \mathrm{g} / \mathrm{mL})$ & Inhibition (\%)* & $I C_{50}(\mu \mathrm{g} / \mathrm{mL})^{*}$ \\
\hline \multirow{5}{*}{ Ethanolic Extract } & 5 & $16.97 \pm 2.78$ & \multirow{5}{*}{$269.12 \pm 14.19$} \\
\hline & 10 & $24.24 \pm 1.05$ & \\
\hline & 50 & $39.39 \pm 2.78$ & \\
\hline & 100 & $47.88 \pm 2.78$ & \\
\hline & 500 & $66.06 \pm 2.77$ & \\
\hline \multirow{5}{*}{ Ethyl Acetate Extract } & 1 & $21.24 \pm 1.72$ & \multirow{5}{*}{$47.15 \pm 1.63$} \\
\hline & 5 & $30.11 \pm 1.44$ & \\
\hline & 10 & $35.90 \pm 2.16$ & \\
\hline & 50 & $53.07 \pm 1.86$ & \\
\hline & 100 & $65.82 \pm 1.87$ & \\
\hline \multirow{5}{*}{ Hydroxyurea } & 250 & $12.79 \pm 1.34$ & \multirow{5}{*}{$2422.50 \pm 102.43$} \\
\hline & 500 & $25.62 \pm 2.72$ & \\
\hline & 1000 & $37.21 \pm 2.68$ & \\
\hline & 2500 & $55.81 \pm 1.90$ & \\
\hline & 5000 & $80.81 \pm 3.49$ & \\
\hline
\end{tabular}




\section{DISCUSSION}

A literature search indicates that there are insufficient published reports about the effects of E. spectabilis inhibitory activities against HDAC, XO and urease. This encouraged us to undertake an experiment on the inhibition activities of ethanolic and ethyl acetate extracts of $E$. spectabilis against these enzymes.

HDAC activities/expressions have been shown to be elevated in cancer patients. More so, overactivity of this enzyme has been associated not only with cancer progression (due to enhanced cell proliferation), but also to cancer induction. Therefore, inhibition of HDAC is at the center of research and paramount for the discovery of new and safe molecules with anticancer properties (20). In our study, both ethanolic and ethyl acetate extracts of $E$. spectabilis were found to have much higher HDAC inhibitory activity than the VPA. On the other hand, it was reported that the anti-radical activity of ethyl acetate extract of $E$. spectabilis was better than the methanolic extract, whereas the phenolic content was higher in the methanolic extract compared to the ethyl acetate extract (21). Plant-based flavonoids are well known secondary metabolites that having a wide variety of chemical constituents, thus strong antioxidant properties (mostly due to their polyphenolic structure). Owing to the capacity of these molecules to block the distortion/diverse effects of crucial pathways and cellular signalling (especially in cancer cells), the molecules are potential and promising anticarcinogenic agent $(13,22)$. It was revealed that $E$. spectabilis is a rich source of isoorientin (a flavonoid compound), a molecule which affected cell proliferation of neuroblastoma cells via cell cycle control (23). In the current study, the HDAC inhibitory activities of both extracts may be associated with the high amounts of phenolic compounds found in E. spectabilis (24). It might also be due to the involvement of other secondary metabolites of the medicinal plant.

$\mathrm{XO}$ is a key rate-limiting enzyme involved in purine metabolism. Increased plasma XO activity is associated with excessive synthesis of uric acid. This predominantly results in hyperuricemia, excessive formation of free radicals and subsequent triggering cancer $(25,26)$. In this case, the most important strategy may be to find out both safe and new molecules for the inhibition of XO. According to the outcomes of our study, ethyl acetate extract exhibited a stronger XO inhibitory activity than the ethanolic extract. Moreover, it was found that ethyl acetate extract exhibited similar effects to allopurinol. $E$. spectabilis is reported to contain flavonoids such as rutin and quercetin (27). Thus, both ethanolic and ethyl acetate extracts inhibited XO activity possibly due to its rutin and quercetin content of E. spectabilis. In addition, quercetin may have contributed to the inhibitory effect by forming a chelate-complex with molybdenum in the active center of $\mathrm{XO}$, hence resulting in a loss of activity $(14,28)$.

The overproduction of ammonia from urea, as a consequence of high urease activity leads to an increase in $\mathrm{pH}$ value. This pro- motes excellent conditions for Helicobacter pylori whose overgrowth comes true, hence the progression of some stomach ailments (for example peptic ulcers, gastritis, arthritis and possibly gastric cancer) (29). Herein, the examined extracts exhibited a notable inhibitory activity against urease, with ethyl acetate extract of $E$. spectabilis having a higher effect. The effective inhibitory activity of ethyl acetate extract can be attributed to the high content of phenolics and flavonoids of the Eremurus species $(30,31)$. Meanwhile, it had been reported that phenolic compounds and flavonoids naturally occurring in fruits/edible plants such as the Eremurus species (rather than only synthetic compounds) are promising novel and potent inhibitors against urease (32).

The limitation of the study is that the in vitro effects of $E$. spectabilis extract on enzymes were considered, and since many disease models are required for in vivo effect.

\section{CONCLUSION}

According to the present findings, ethanolic and ethyl acetate extracts of $E$. spectabilis had apparent inhibitory activities against all examined enzymes. Meanwhile, the ethanolic extract showed a better inhibitory effect on HDAC than the ethyl acetate extract. On the other hand, the inhibitory activities of the ethyl acetate extract against both the $\mathrm{XO}$ and urease were higher than that of the ethanolic extract. The inhibitory effects exerted by this plant make E. spectabilis an interesting candidate for medicinal use, either in the form of crude extracts or as a source of bioactive compounds.

Ethics Committee Approval: Ethics committee approval is not required because of no material or experimental animal that would require permission.

Peer-review: Externally peer-reviewed.

Author Contributions: Conception/Design of Study - B.B.B., R.Y.; Data Collection and/or Processing - B.B.B., R.Y.; Analysis and/or Interpretation - B.B.B., R.Y.; Writing - B.B.B., R.Y.

Conflict of Interest: The authors have no conflict of interest to declare.

Financial Disclosure: This work was funded by Istanbul University-Cerrahpasa Scientific Research Projects Committee. Project number: 52245.

Etik Komite Onayı: Bu calışmada, etik komite iznine gerek duyulacak bir materyal ya da deney hayvanı kullanılmamıştır.

Hakem Değerlendirmesi: Dış bağımsız.

Yazar Katkıları: Çalışma Konsepti/Tasarımı - B.B.B., R.Y.; Veri ToplamaB.B.B., R.Y.; Veri Analizi/Yorumlama - B.B.B., R.Y.; Yazma - B.B.B., R.Y.

Çıkar Çatışması: Yazarlar çıkar çatışması bildirmemişlerdir.

Finansal Destek: Bu calışma İstanbul Universitesi-Cerrahpaşa Bilimsel Araştırma Projeleri Komitesi tarafından finanse edilmiştir. Proje numarası: 52245. 


\section{REFERENCES}

1. Yuan $H$, Ma $Q$, Ye L, Piao $G$. The traditional medicine and modern medicine from natural products. Molecules 2016; 21(5): 559. [CrossRef]

2. The genus Eremurus. (2021, May 03). Available from: http://www. theplantlist.org/tpl1.1/search?q=Eremurus

3. Salehi B, Ayatollahi SA, Segura-Carretero A, Kobarfard F, Contreras MDM, Faizi M, et al. Bioactive chemical compounds in Eremurus persicus (Joub. \& Spach) Boiss. essential oil and their health implications. Cell Mol Biol 2017; 63(9): 1-7. [CrossRef]

4. Cinar A, Ay ST, Ayas, F, Karabak S, Guzelsoy N, Ucurum O. Foxtail lilly (Eremurus spectabilis M. Bieb.) as priority species biodiversity for food and nutrition project of Turkey. Anadolu J Aegean Agric Res Inst 2017; 27(2): 69-73.

5. Aysu T, Demirbaş A, Bengü AŞ, Küçük MM. Evaluation of Eremurus spectabilis for production of bio-oils with supercritical solvents. Process Saf Environ Prot 2015; 94: 339-49. [CrossRef]

6. Tosun M, Ercisli S, Ozer H, Turan M, Polat T, Ozturk E, et al. Chemical composition and antioxidant activity of foxtail lily (Eremurus spectabilis). Acta Sci Pol Hortorum Cultus 2012; 11(3): 145-53.

7. Gaggeri R, Rossi D, Mahmood K, Gozzini D, Mannucci B, Corana F, et al. Towards elucidating Eremurus root remedy: Chemical profiling and preliminary biological investigations of Eremurus persicus and Eremurus spectabilis root ethanolic extracts. J Med Plant Res 2015; 8(41): 1038-48. [CrossRef]

8. Gaggeri R, Rossi D, Azzolina O, Ahmed KM, Avanzini A, Mantelli M, et al. Anti-inflammatory properties of ethanolic root extract of Eremurus persicus (Jaub and Spach) Boiss, a Kurdish herbal remedy. J Med Plant Res 2013; 7(23): 1730-5.

9. Dashti M, Tavakoli H, Zarif Ketabi H, Paryab A. Ecological requirements of plant of Eremurus (Eremurus spectabilis MB) in Khorasan province. Iran J Range Desert Res 2005; 12(2): 153-65.

10. Prakash V, Sagar A. Analysis of Achyranthes aspera L. extracts for their a-amylase and urease inhibitory activities. J Drug Deliv Ther 2021; 11(2): 108-12. [CrossRef]

11. Phaniendra A, Jestadi DB, Periyasamy L. Free radicals: Properties, sources, targets, and their implication in various diseases. Indian J Clin Biochem 2015; 30(1): 11-26. [CrossRef]

12. Ganai SA. Plant-derived flavone apigenin: The small-molecule with promising activity against therapeutically resistant prostate cancer. Biomed Pharmacother 2017; 85: 47-56. [CrossRef]

13. Ganai SA, Sheikh FA, Baba ZA. Plant flavone Chrysin as an emerging histone deacetylase inhibitor for prosperous epigenetic-based anticancer therapy. Phytother Res 2021; 35(2): 823-34. [CrossRef]

14. Bortolotti M, Polito L, Battelli MG, Bolognesi A. Xanthine oxidoreductase: One enzyme for multiple physiological tasks. Redox Biol 2021; 41: 101882. [CrossRef]

15. Battelli MG, Bortolotti M, Polito L, Bolognesi A. Metabolic syndrome and cancer risk: The role of xanthine oxidoreductase. Redox Biol 2019; 21: 101070. [CrossRef]

16. Khan MA, Aslam M, Shahzad SA, Khan ZA, Khan NA, Ali M, et al. Design and synthesis of thiobarbituric acid analogues as potent urease inhibitors. J Mol Struct 2021; 1231: 129959. [CrossRef]

17. Phull AR, Ali A, Rafiq M, Tahir T, Majid A, Seo SY, et al. Antioxidant potential, urease and acetylcholine esterase inhibitory activity and phytochemical analysis of selected medicinal plants from the Republic of Korea. Explor Res Hypothesis Med 2021; 6(2): 51-59. [CrossRef]
18. Abdullahi A, Hamzah RU, Jigam AA, Yahya A, Kabiru AY, Muham$\operatorname{mad} \mathrm{H}$, et al. Inhibitory activity of xanthine oxidase by fractions Crateva adansonii. J Acute Dis 2012; 1(2): 126-9. [CrossRef]

19. Van Slyke DD, Archibald RM. Manometrie, titrimetric and colorimetric methods for measurements of urease activity. J Biol Chem 1944; 154: 623-42. [CrossRef]

20. Ganai SA, Sheikh FA, Baba ZA, Mir MA, Mantoo MA, Yatoo MA. Anticancer activity of the plant flavonoid luteolin against preclinical models of various cancers and insights on different signalling mechanisms modulated. Phytother Res 2021 Feb 13. [Epub ahead of print]. [CrossRef]

21. Karaman K, Polat B, Ozturk I, Sagdic O, Ozdemir C. Volatile compounds and bioactivity of Eremurus spectabilis (Ciris), a Turkish wild edible vegetable. J Med Food 2011; 14(10): 1238-43. [CrossRef]

22. Ghasemi S, Xu S, Nabavi SM, Amirkhani MA, Sureda A, Tejada S, et al. Epigenetic targeting of cancer stem cells by polyphenols (cancer stem cells targeting). Phytother Res 2021 Feb 22. [Epub ahead of print]. [CrossRef]

23. Karaoglan ES, Gundogdu G, Secme M, Onur S, Miloglu FD, Dodurga $Y$, et al. Eremurus spectabilis, rich source of isoorientin: Isolation, quantification and anti-cancer activity on SH-SY5Y neuroblastoma cells. Curr Pharm Anal 2018; 14(6): 578-85. [CrossRef]

24. Abubaker SR, Hidayat HJ. Anti tumor potential of local aslerk (Eremurus spectabilis) leaf extracts by HPLC and applying on cancer cell lines in vitro. Iraqi J Cancer Med Genet 2015; 8(2): 123-8.

25. Burmaoglu S, Ozcan S, Balcioglu S, Gencel M, Noma SAA, Essiz S, et al. Synthesis, biological evaluation and molecular docking studies of bis-chalcone derivatives as xanthine oxidase inhibitors and anticancer agents. Bioorg Chem 2019; 91: 103149. [CrossRef]

26. Xu H, Li C, Mozziconacci O, Zhu R, Xu Y, Tang Y, et al. Xanthine oxidase-mediated oxidative stress promotes cancer cell-specific apoptosis. Free Radic Biol Med 2019; 139: 70-9. [CrossRef]

27. Bircan B, Kırbağ S. Determination of antioxidant and antimicrobial properties of Eremurus spectabilis Bieb. Artvin Çoruh Üniv Orman Fak Derg 2015; 16(2): 176-86. [CrossRef]

28. Symonowicz $M$, Kolanek M. Flavonoids and their properties to form chelate complexes. Biotechnol Food Sci 2012; 76(1): 35-41.

29. El Aanachi S, Gali L, Rammali S, Bensouici C, Aassila H, Dari K. In vitro study of the antioxidant, photoprotective, anti-tyrosinase, and anti-urease effects of methanolic extracts from leaves of six Moroccan Lamiaceae. J Food Meas Charact 2021; 15(2): 1785-95. [CrossRef]

30. Karakaya L, Akgül Y, Nalbantsoy A. Chemical constituents and in vitro biological activities of Eremurus spectabilis leaves. Nat Prod Res 2017; 31(15): 1786-91. [CrossRef]

31. Mushtaq A, Hussein Masoodi M, Farooq Wali A, Ganai A. Total phenolic content, total flavonoid content, in vitro antioxidant activity and antimicrobial activity against human pathogenic bacteria of Eremurus himalaicus-An edible herb of North Western Himalayas. Free Radic Antiox 2017; 7(1): 90-4. [CrossRef]

32. Nile S, Keum YS, Nile AS, Jalde SS, Patel RV. Antioxidant, anti-inflammatory, and enzyme inhibitory activity of natural plant flavonoids and their synthesized derivatives. J Biochem Mol Toxicol 2017; 32(1): e22002. [CrossRef] 